\title{
Kierunki rozwoju informacji i sytuacja informacyjna użytkownika książki
}

\author{
Stanisława Kurek-Kokocińska \\ Katedra Bibliotekoznawstwa i Informacji Naukowej \\ Uniwersytet Łódzki
}

\begin{abstract}
Abstrakt
Cel/teza: Celem jest charakterystyka dokumentu IFLA Rapport sur les tendances oraz rozważenie na tym tle sytuacji użytkownika książki.

Koncepcja/metody badań: Zastosowano metody: omówienie zawartości publikacji IFLA, analiza wybranej literatury, interpretacja danych źródłowych, opis i ocena kilku przypadków obrazujących sytuację użytkownika-czytelnika.

Wyniki i wnioski: Prognoza uwzględnia: (1) dostępność informacji, (2) e-nauczanie, (3) bezpieczeństwo i ochrona życia prywatnego, (4) zaangażowanie obywatelskie, (5) zarządzanie informacją; akcentuje rozwój modeli biznesowych w dostępie do informacji. Korzystanie z obecnych w Sieci informacji o istniejących publikacjach może kierować użytkownika-czytelnika do biblioteki; nierzadko stawia go w sytuacji klienta określonych firm, ułatwia zakup tekstu i dostarcza obserwatorom rynku określonych wiadomości. Świat cyfrowy, oferując dostęp do informacji o książkach, może usposabiać do poruszania się w tej przestrzeni na poziomie informacji hasłowych i skrótów. Aktualne staje się pytanie, jak na te sytuacje zareagują użytkownicy?

Oryginalność/wartość poznawcza: Przedstawiona analiza przybliża treść dokumentu IFLA i stanowi głos w dyskusji na temat zawartych tam prognoz. W dotychczasowym piśmiennictwie brak jest wypowiedzi poruszającej podjęty temat.
\end{abstract}

\section{Słowa kluczowe}

Dostęp do informacji. Epoka cyfrowa. Informacja. Internet. Lektura. Społeczeństwo informacyjne. Użytkownik informacji.

Otrzymany: 13.05.2014. Poprawiony: 4.06.2014. Zaakceptowany: 6.06.2014.

\section{Wprowadzenie}

Inspiracją do powstania artykułu była lektura opracowania sporządzonego przez ekspertów zaproszonych przez IFLA (International Federation of Library Associations and Institutions) i opublikowanego w jedenastu językach, w tym w języku francuskim jako À la crête des vagues, ou submergé par la marée? Naviguer dans un environnement de l'information en mutation. Aperçu du Rapport sur les tendances [Na grzbiecie fali czy pod wodą? Surfowanie w środowisku zmieniającej się informacji. Raport o tendencjach] (IFLA, 2013) [dalej: Raport]. Dokument ten został przedstawiony w sierpniu 2013 r. przed światowym Kongresem Bibliotek i Informacji, który odbył się w Singapurze.

W pierwszej części prezentowanego artykułu przedstawiam i charakteryzuję główne twierdzenia zawarte w tym dokumencie. Następnie rozważam sytuację użytkownika informacji piśmienniczej, skupiając uwagę jedynie na dostępności informacji i treści 
opublikowanych książek. W tym celu analizuję wybraną literaturę przedmiotu oraz dane źródłowe zawarte w publikowanych raportach z badań oraz podejmuję krytyczny opis kilku kontrolnie sprawdzonych przypadków, wpisujących się w modelową sytuację problemową użytkownika piśmiennictwa.

\section{Tendencje}

Spostrzeżenia i refleksje zespołu autorskiego odpowiedzialnego za Raport, zostały tak sformułowane, by zmieścić je można było w zaledwie kilku punktach. Ogólnie mówiąc, tendencje te są następujące: (1) dostępność informacji, (2) e-nauczanie, (3) bezpieczeństwo i ochrona życia prywatnego, (4) zaangażowanie obywatelskie, (5) zarządzanie informacją związane z rozwojem technologii mobilnych.

Jest to w gruncie rzeczy spojrzenie na przyszłość ludzkiego życia i prognoza funkcjonowania człowieka w przestrzeni cyfrowej. Kierunek przewidywań oraz bliższe perspektywy na następne lata determinuje ścisły związek z technologią oparty na następujących przesłankach: obserwacja ilości istniejącej informacji, utrzymanie jej dalszego wzrostu w szybkim tempie oraz intensywny rozwój technologii mobilnych uwzględniających tzw. ślad cyfrowy. Z lektury dokumentu IFLA jasno wynika nieuchronność przejścia do fazy cyfrowej społeczeństw w skali globalnej. Jest tu bowiem mowa również o tym, jak informacja dostępna za pomocą technologii, przekształci dotychczasowe warunki życia i jak zmieni istniejące praktyki społeczne. W procesie, o którym mowa, rolę odgrywa konieczność oraz gotowość i chęć komunikowania się w przestrzeni cyfrowej, a także łatwość przekazywania treści cyfrowych na różnych platformach (nowe treści, multiplikacja). Duże znaczenie w toku dokonujących się zmian ma aktywność użytkowników informacji cyfrowej, prezentujących swoje zapatrywania w różnych sprawach i własne poczynania właśnie za pośrednictwem technologii.

Wskazane przez IFLA trendy w rozwoju informacji określają jednocześnie pole refleksji nad kierunkami społecznych przemian, których doświadczamy i których implikacje dają pole do prognozowania.

(1) „Les nouvelles technologies élargiront et limiteront à la fois l'accès à l'information" [Nowe technologie jednocześnie poszerzą, jak i ograniczą dostęp do informacji].

Wśród zagadnień związanych z dostępem do informacji autorzy IFLA na pierwszym miejscu stawiają znaczenie kompetencji informacyjnych, obejmujących przygotowanie, obycie i łatwość posługiwania się technologiami cyfrowymi. Umiejętności te są potrzebne do poruszania się w świecie informacji, tak wśród treści cyfrowych obiektywnych, jak i pośród treści nieobiektywnych, będących np. pod wpływem celowych programów i oddziaływań osób czy grup.

Podzielając przedstawiony punkt widzenia, trzeba zauważyć, iż, dokonywany przez użytkownika z mnóstwa informacji wybór, ma za podstawę indywidualny potencjał wiedzy, rozumienia i zainteresowań poszczególnych osób. Kształtowanie tych przymiotów i ich polepszanie nie ogranicza się - przynajmniej dzisiaj - do oddziaływania przekazu cyfrowego. 
(2) „L'enseignement en ligne démocratisera et déstabilisera l'apprentissage à l'échelle mondiale" [Edukacja on-line zdemokratyzuje i zdestabilizuje nauczanie na skalę światową].

Nauczanie i edukacja jako kwestia o kluczowym dla przyszłości znaczeniu, poddawana jest w epoce cyfrowej licznym przekształceniom. W dokumencie IFLA powiedziano więcej na temat możliwego wzrostu popularności e-nauczania. W opinii autorów, praktyki korzystające z nowych sposobów kształcenia, pociągają za sobą następstwa, szczególnie ważne dla dotychczasowych modeli organizacyjnych i metod nauczania. Obszar dokonanej refleksji objął m.in.: masowość i światowy zasięg kursów online oraz ich dostępność, łatwość ustalania i zmieniania programów nauczania, a także uznawanie wartości uzyskanego tą drogą wykształcenia na równi z wykształceniem „stacjonarnym” (np. uniwersyteckim). Rynek nauczania w przyszłości, jak twierdzą eksperci, zdaje się być narażony na skutki połączenia i ekspansji firm internetowych, oferujących treści i platformy dla różnych grup odbiorców, co umniejszy znaczenie dotychczasowej organizacji i infrastruktury.

(3) „Les limites de la protection de la vie privée et des données seront redessinées” [Granice ochrony prywatności i osobistych danych zostaną zredefiniowane].

Aktualne doświadczenie klienta, konsumenta czy obywatela wystarcza, by nasunęły się pytania o ochronę prywatności oraz zagadnienie poczucia własnego bezpieczeństwa. W grę wchodzi tu problem danych cyfrowych, które pochodzą z różnych systemów monitorowania instytucji i przestrzeni publicznej, nadzoru używanych systemów komputerowych, połączeń interaktywnych oraz śledzenia aktywności komercyjnej obywateli. Całość tego rodzaju danych przechowywanych przez rządy i instytucje jest kapitałem, który stwarza ogromne możliwości korzystania z tych zasobów i operowania nimi, dając łatwość np.generowania profilów osób.

(4) „Dans les sociétés hyperconnectées, de nouvelles voix et de nouveaux groupes pourront se faire entendre" [W społecznościach wysoce usieciowionych mają szansę dojść do głosu nowe grupy i jednostki].

Wizja nakreślona w dokumencie IFLA kieruje uwagę na sytuacje, które mogą stać się udziałem szerszych grup użytkowników Internetu. Z jednej strony jest to łatwość włączenia się obywateli w życie zbiorowe i publiczne, co może oddziaływać np. na sektor władzy i działalność partii politycznych, z drugiej jednak - niesie konsekwencje w postaci oddziaływania na wybory i decyzje podejmowane przez obywateli. Autorzy sygnalizują niebezpieczeństwo forsowania tą drogą myśli i postaw odpowiadających interesom środowisk zabiegających o popularność i o swoje korzyści (cyberterroryzm, cyberprzestępstwa i in.).

(5) „Les nouvelles technologies transformeront l'économie mondiale de l'information” [Nowe technologie zmienią światową ekonomię informacji].

Nowy model funkcjonowania świata w opinii ekspertów IFLA prezentuje przyszłość pod znakiem mobilnych technologii i licznych współpracujących ze sobą urządzeń, sieci czujników, przekazu trójwymiarowego oraz udoskonalonych technik e-tłumaczenia. Takie nowatorskie technologie mogą w skali światowej zmienić sposób gospodarowania informacją, tak w działalności wytwórczej, jak i w codziennym funkcjonowaniu w zakresie zdrowia, nauczania, finansów czy w sferze informacji publicznej. W otoczeniu „myślących” komputerów, wyposażonych w technologie rozpoznawania głosu, automatyczne tłumaczenie 
i syntetyzowanie wypowiedzi oraz interaktywny intuicyjny interfejs, a także za przyczyną takich domen, jak telepraca, telezdrowie, teleopieka może nastać czas zupełnie innego życia społecznego i funkcjonowania naszej cywilizacji.

$\% * \%$

Należy zauważyć, że eksperci IFLA wyszli poza krąg spraw bibliotekarstwa i jasno wskazują, że sektor IT szuka i zajmuje dla siebie pola istotne dla funkcjonowania świata, zarówno w teraźniejszości, jak i w przyszłości. Te pola to przede wszystkim nowe modele biznesowe, przynoszące korzyści grupom dostawców i pośredników w dostępie do informacji. Sektor technologiczny jest obecny w dziedzinie obrotu towarów i usług, monitorowania osób i instytucji, wkracza na rynek edukacyjny, może wymagać zmian modeli wytwórczości (przemysłów). Nowa sytuacja niesie z sobą zagrożenia, zwłaszcza w sferze ochrony prywatności, stabilności funkcjonowania edukacji, w zakresie własności intelektualnej (wobec działań na materii informacji następuje jej „oderwanie” od właściciela).

Lektura dokumentu IFLA, zawierającego przewidywania i prognozy ukierunkowane na funkcjonowanie społeczeństwa w świecie przyszłości, w epoce cyfrowej, zachęca do zabrania głosu i wypowiedzenia się w tej sprawie. Trudno przy tym nie oprzeć się na indywidualnym doświadczeniu użytkownika Internetu, który korzysta z Sieci z zamiarem dostępu do dzieł i ich studiowania.

\section{Użytkownik w społeczeństwie informacyjnym}

Jak była mowa wyżej, tendencje rozwoju informacji, zdefiniowane w publikacji IFLA, implikuje kontekst technologiczny, a przede wszystkim temat Internetu. Ta platforma komunikacyjna, działająca w różnych krajach, skupia na sobie uwagę nauki, władz oraz innych pionów życia we współczesnym świecie. Rozwój Internetu to temat szeroki, a jedną z kluczowych kwestii są zagadnienia społeczeństwa informacyjnego.

Więcej światła na powyższą tematykę, w odniesieniu do naszego kraju, dostarczają opracowania Głównego Urzędu Statystycznego i Departamentu Społeczeństwa Informacyjnego Ministerstwa Administracji i Cyfryzacji. Charakterystyka społeczeństwa informacyjnego dotyczy m.in. infrastruktury dostępu do Internetu, wyposażenia przedsiębiorstw i wykorzystania technologii informacyjno-komunikacyjnych w przedsiębiorstwach, gospodarstwach domowych, administracji publicznej oraz w wybranych gałęziach gospodarki. Warto nadmienić, że w Polsce w 2012 r. ponad 7 na 10 gospodarstw domowych miało w domu przynajmniej jeden komputer (GUS, 2012, 90) i korzystało z Internetu niemal 70\% ogółu społeczeństwa; regularnie, czyli co najmniej raz w tygodniu korzystało z Internetu 87\% osób, a dwie trzecie osób codziennie (MAC, 2013, 37).

Rozpoznane cele korzystania z Internetu w Polsce obejmują szereg czynności indywidualnych praktykowanych w nowoczesny sposób, według dzisiejszych standardów funkcjonowania w poszczególnych dziedzinach życia. Jak czytamy w publikacji Społeczeństwo informacyjne w liczbach (MAC, 2012b, 68) w latach 2005-2010 były to: komunikowanie się, wyszukiwanie informacji o produktach, szkolenie i kształcenie, usługi bankowe, wyszukiwanie informacji o zdrowiu, słuchanie radia i oglądanie telewizji, granie w gry, pobieranie plików, korzystanie z serwisów o tematyce podróżniczej, czytanie, szukanie pracy, wysyłanie 
ofert w sprawie zatrudnienia, sprzedaż towarów i usług. Cele używania Internetu przez obywateli w wybranych sprawach prywatnych, ustalone w następnych latach i opisane $\mathrm{w}$ dokumencie Spoteczeństwo informacyjne w Polsce. Wyniki badań statystycznych z lat 2008-2012 (GUS, 2012, 116-117) obejmują podobne czynności, przy czym korzystanie poprzez urządzenia przenośne uwzględniło również czytanie online lub pobieranie e-booków (GUS, 2012, 130).

W badaniach zleconych przez Ministerstwo Administracji i Cyfryzacji, zrealizowanych w 2010 i 2012 r. według innej metodologii, jako kluczowe obszary życia, w których korzystamy z Internetu, wyodrębnione zostały nieco inne cele. W 2010 r. pośród dziesięciu najważniejszych wskazań znalazły się (w kolejności): stosowanie zabezpieczeń do ochrony komputera; dokonywanie transakcji bankowych przez Internet; dostęp do wiedzy fachowej związanej z zawodem; ostrzeganie przez Internet o zagrożeniach meteorologicznych; podnoszenie umiejętności korzystania z komputera i Internetu; ostrzeganie o zagrożeniach związanych z działalnością człowieka (terroryzm, katastrofy); dostęp do placówek medycznych i ich usług; dostęp do rozkładów jazdy; ostrzeganie o występowaniu chorób zakaźnych i epidemii a także dostęp do rozkładu jazdy środków komunikacji międzynarodowej (MAC, 2010, 50). Edycja badań wykonanych w 2012 r. zmodyfikowała uzyskane wcześniej rezultaty, wysuwając na pierwsze miejsce dostęp do ofert pracy (89\% określane jako ważne i raczej ważne) (MAC, 2012a).

Innym badaniem ogólnopolskim, którego wyniki rzucają światło na społeczność internautów, jest badanie panelowe realizowane od 2000 r. przez Wyższą Szkołę Finansów i Zarządzania oraz Radę Monitoringu Społecznego. Z przeglądu materiałów (m.in. opublikowane kwestionariusze oraz publikacja końcowa) pod ogólnym tytułem Diagnoza społeczna, wynika, że realizatorzy badania w ankiecie skierowanej do respondentów w treści pytania zawierającego listę kilkunastu spraw, które mogą być załatwiane przez Internet, kilkakrotnie (tj. w latach 2007-2011) uwzględnili punkt „dostęp do bibliotek publicznych (przeszukiwanie katalogów, wypożyczanie książek)”. Uzyskane odpowiedzi przedstawiają się skromnie, w 2007 r. odsetek ten wyniósł $25.6 \%$, w 2009 r. - 26.5\% oraz w 2011 r. - 25\% respondentów (Diagnoza, 2011, 326-327). W edycji badania z 2013 r. formularz ankiety skierowanej do respondentów nie diagnozował tej kwestii, zawierał inne pytania dotyczące wykorzystania 26 różnych zastosowań Internetu (Diagnoza, 2013).

Przegląd zaledwie kilku ogólnopolskich pomiarów zrealizowanych wśród użytkowników Internetu obrazuje główne poczynania obywateli w świecie online, a zwłaszcza korzystanie z technologii przez użytkowników do załatwiania prywatnych spraw.

Nie sposób nie odnotować, że wśród uzyskanych wyników znajdujemy komunikat istotny dla kręgów bibliotekarskich, świadczący o uznaniu przez internautów ważności informacji wytworzonej przez tę grupę zawodową.

Lektura raportów może nasuwać pytania (np. obecność i wielkość danych procentowych w zakresie dostępu do ofert pracy), jednak dane z okresu kilku lat mają swoją wymowę. Powtórzmy: dostęp do katalogów bibliotek przez Internet był ważny i raczej ważny dla znacznej grupy osób badanych: w 2008 - dla 71\%; w 2010 - w rozbiciu na ważne dla 56\% i raczej ważne - dla 22\% badanych; w 2012: był ważny dla 36\% i raczej ważny dla 39\% ogółu ankietowanych osób (MAC, 2010; MAC, 2012a).

Trzeba też dodać, iż przegląd wyników zawartych w kilku uwzględnionych publikacjach, obrazuje również podejście środowiska badaczy do zagadnienia użytkowania Internetu. 
Np.w badaniach prowadzonych przez GUS treść ankiet, o czym czytamy w opisie metodologii tych badań, jest konsultowana z ministerstwami, urzędami szczebla centralnego i wojewódzkiego, ze środowiskiem naukowym i przedstawicielami biznesu. Inne zespoły ankietujące posługiwały się własnymi kwestionariuszami. Ogólnie mówiąc, daje się zauważyć, że zamysł rozpoznania zachowań użytkowników indywidualnych ogniskował się wokół tematu zdrowia i życia, zatrudnienia oraz oferty cyfrowej skierowanej do klienta, rozumianego jako użytkownika towarów i usług z różnych dziedzin. W przywołanych badaniach, ich autorów interesowała też kwestia korzystania przez obywateli, ze skierowanej do uczestnika przekazu cyfrowego oferty w zakresie kultury (radio, telewizja, czasopisma, gry, muzea, galerie, książki).

\subsection{Użytkownik książki: egzemplifikacje sytuacji informacyjnej $i$ ich analiza}

Zamierzoną próbą zwrócenia uwagi na współczesną sytuację odbiorcy tekstów kultury obecnych w Internecie, może być przyjrzenie się kilku przykładom, skupionym na doświadczeniu i obserwacji zachowań użytkownika informacji piśmienniczej i czytelnika książek. Wydaje się ono ciekawe tym bardziej, że dostęp do katalogów bibliotecznych, został dostrzeżony jako grupa treści obecna w Internecie, czytanie online interesuje użytkowników Sieci, a przecież eksperci IFLA w Raporcie właśnie kreślą wizję świata zdominowanego przez cyfrowe informacje. Powołując się na formę książki, stosuję redukcję, która jest konieczna dla jasności niniejszej wypowiedzi. Teoretycznie, trzeba objąć uwagą egzemplifikacje wpisujące się w jedną z dwóch modelowo odrębnych sytuacji dyktowanych:

(1) (Sytuacja 1) potrzebą pozyskania informacji o konkretnej książce oraz jej tekstu; można przypuszczać, że autor lub/i tytuł są znane użytkownikowi;

(2) (Sytuacja 2) potrzebą pozyskania informacji o piśmiennictwie na dany temat oraz właściwych tekstów; w tym punkcie trzeba rozróżnić dalsze warianty sytuacji:

a. piśmiennictwo zostało wskazane przez inne osoby, np. nauczyciela, innego autora (bibliografia załącznikowa, bibliografie tematu, dziedziny, inne);

b. piśmiennictwo nie jest użytkownikowi znane, nie dysponuje on określonymi wskazówkami w zakresie literatury przedmiotu.

Rozpatrując konkretny materiał ilustracyjny (Sytuacja 1 i Sytuacja 2), przeniesiemy rozważanie na grunt realnie dostępnych źródeł informacji o publikacjach ${ }^{6}$ i ich treści, co będzie następnie okazją do interpretacji opinii o poszerzaniu i limitowaniu dostępu do informacji (Tendencja 1).

\section{Sytuacja 1.}

Sytuacja 1.1 .

Na tym przykładzie widać, że cyfrowe zasoby informacji obecne w Sieci nie niosą ze sobą dostępu do treści poszukiwanej książki. Warto dodać, że Pasja poznawania jest tłumaczeniem z języka angielskiego, zawiera wypowiedzi udzielone przez uczonych światowej sławy na antenie BBC.

${ }^{6}$ Do egzemplifikacji użyto narzędzi wyszukiwawczych Biblioteki Narodowej (katalog), NUKAT, FBC oraz wyszukiwarki internetowej [stan na 31.03.2014]. 
Tabela 1. Sytuacja użytkownika poszukującego informacji i tekstu książki pt. Pasja poznawania (Wolpert \& Richards, Warszawa, 1999)

\begin{tabular}{|c|c|c|}
\hline \multicolumn{2}{|c|}{ W środowisku Internetu } & W bibliotece (placówka) \\
\hline $\begin{array}{l}\text { WYNIKI: informacje handlowe (księ- } \\
\text { garska, antykwaryczna) (+ dodatkowe } \\
\text { charakterystyki) } \\
\text { WYNIKI: informacje uwzględnione } \\
\text { w innych tekstach (wzmianki, opi- } \\
\text { nie, strona z cytatami dla tej książki } \\
\text { pt. „Spisy książek z odnośnikami do } \\
\text { cytatów”) } \\
\text { WYNIKI: informacje zawarte w SIW } \\
\text { (biblioteczne, bibliograficzne) }\end{array}$ & $\begin{array}{l}\text { WYNIKI: } \\
\text { brak dostępu do } \\
\text { treści }\end{array}$ & $\begin{array}{l}\text { informacje: siw } \\
\text { (własny, współpraca) } \\
\text { TREŚC: dostęp na miejscu, } \\
\text { wypożyczenie }\end{array}$ \\
\hline
\end{tabular}

Sytuacja 1.2.

Tabela 2. Sytuacja użytkownika poszukującego informacji i tekstu książki pt. Nowe obszary i drogi rozwoju edukacji muzycznej (pod red. A. Białkowskiego, Warszawa, 2012)

\begin{tabular}{|l|l|l|}
\hline \multicolumn{2}{|c|}{ W środowisku Internetu } & \multicolumn{1}{|c|}{ W bibliotece (placówka) } \\
\hline WYNIKI: informacje uwzględnione & & \\
w innych tekstach (nawiązania, & WYNIKI: & informacje: siw \\
wzmianki) & dostęp do treści & (własny, współpraca) \\
WYNIKI: informacje uwzględnione & w portalu instytucji & TREŚĆ: dostęp na miejscu, \\
w portalu instytucji sprawczej (wydawcy) & sprawczej & wypożyczenie \\
WYNIKI: informacje zawarte w SIW & & \\
(biblioteczne, bibliograficzne) & & \\
\hline
\end{tabular}

Niniejszy opis obrazuje przykład dokumentu opublikowanego w Sieci w portalu wydawcy, którego wersja drukowana została włączona również do zbiorów bibliotecznych. Warto zauważyć, że książka naukowa specjalistyczna jest słabiej widoczna w Sieci, zwłaszcza mniej liczne są przywołania czy wzmianki wyszukane i pokazane przez ogólną wyszukiwarkę.

Inna kwestia tu się pojawiająca to uwidocznienie wzajemnych relacji między tekstem w obu równoległych formach jego prezentacji. Problem ten jest ważny, został też zauważony, o czym świadczą praktyki, jakie napotkać można w katalogach (link do nieodpłatnej wersji elektronicznej o uregulowanej sytuacji w zakresie prawa autorskiego). Nie jest przy tym to problem łatwy do rozwiązania, mocno łącząc się z nowymi modelami biznesowymi, jak można by powiedzieć za Raportem. Ilustracją może tu być działalność publikacyjna Fundacji „Instytut Spraw Publicznych”, organizacji pozarządowej, wydawcy licznych opracowań naukowych. Użytkownik Internetu zaciekawiony np. książką pt. Kobiety, wybory, polityka (red. M. Fuszar, Warszawa, 2013) czyta komunikat: „40 zł wersja drukowana”, „30 zł wersja elektroniczna (przelew)" (ISP, 2014b). Nie ma w tym nic dziwnego, bowiem - jak wiemy, i jak zostało tam także napisane,

Elektroniczne książki (e-książki) są odpowiednikami tradycyjnych książek wydanych na papierze, jednak w odróżnieniu od nich, dostępne są w postaci plików komputerowych w formacie PDF (ISP, 2014a). 
Sytuacja 2.

Przykłady rozpatrzone w tej grupie obejmują sytuacje inspirowane istniejącą literaturą przedmiotu (Sytuacja 2a) oraz sytuacje warunkowane chęciami poznania konkretnego tematu (swobodne poszukiwanie piśmiennictwa) przez potencjalnego użytkownika (Sytuacja 2b).

W części pierwszej kierujemy uwagę na kilka tytułów książek biograficznych o Fryderyku Chopinie (Pikulska, 2009).

Sytuacja 2a.

Tabela 3. Sytuacja użytkownika poszukującego informacji i tekstu książek pt. Chopin* Jarosława Iwaszkiewicza, Życie Chopina** Kazimierza Wierzyńskiego,

Życie Chopina Juliusza Kadena-Bandrowskiego, Młodość Chopina**** Adolfa Nowaczyńskiego.

\begin{tabular}{|c|c|c|}
\hline \multicolumn{2}{|c|}{ W środowisku Internetu } & W bibliotece (placówka) \\
\hline $\begin{array}{l}\text { WYNIKI: informacje han- } \\
\text { dlowe (księgarska, anty- } \\
\text { kwaryczna) (+ dodatkowe } \\
\text { charakterystyki) } \\
\text { WYNIKI: informacje } \\
\text { uwzględnione w innych } \\
\text { tekstach (wzmianki, komen- } \\
\text { tarze, recenzje, powołania } \\
\text { i in.) } \\
\text { WYNIKI: informacje za- } \\
\text { warte w SIW (biblioteczne, } \\
\text { bibliograficzne) }\end{array}$ & $\begin{array}{l}\text { WYNIKI: } \\
\text { *) kilka wybranych edycji } \\
\text { w reprodukcji Cyfrowej Biblio- } \\
\text { teki Narodowej (link z katalogu } \\
\text { do POLONA), jednak brak dostępu } \\
\text { do tych treści online, tylko lokalnie: } \\
\text { - Warszawa: PIW, 1995 } \\
\text { - Kraków: PWMuz., 1987; } \\
\text { - Lwów: Państw. Wydaw. Szkolnych, } \\
\text { druk } 1938 \text { (edycja pt. Szopen) } \\
\text { **) kilka wybranych edycji } \\
\text { w reprodukcji Cyfrowej Biblio- } \\
\text { teki Narodowej (link z katalogu } \\
\text { do POLONA), jednak brak dostępu } \\
\text { do tych treści online, tylko lokalnie: } \\
\text { - Białystok: KAW, 1999; } \\
\text { - Kraków: Wydaw. Liter., 1978 } \\
\text { ***) zapowiedź [12.05.2014] digita- } \\
\text { lizacji przez Pomorską Bibliotekę } \\
\text { Cyfrową edycji: } \\
\text { - Warszawa: „RÓJ”, 1939 }\end{array}$ & $\begin{array}{l}\text { informacje: siw } \\
\text { (własny, współpraca) } \\
\text { TREŚĆ dostęp na miej- } \\
\text { scu, } \\
\text { wypożyczenie }\end{array}$ \\
\hline
\end{tabular}

W komentarzu do przykładów rozpatrywanych powyżej trzeba ponownie zauważyć, że wielość obecnych w Sieci informacji dotyczących książek tu przywołanych nie łączy się z możliwością dostępu do tych tekstów w przestrzeni cyfrowej. Dotyczy to również książek zeskanowanych i włączonych do zasobów biblioteki cyfrowej. Właściwym miejscem dojścia do treści okazuje się być kontakt bezpośredni z biblioteką.

Kolejna sytuacja, na którą warto zwrócić uwagę, odnosi się do zapotrzebowania na informacje i piśmiennictwo z zakresu pisania dysertacji. Wątek ten jest w Internecie dobrze znany i popularny. Wyszukiwarki ogólne wydobywają z zasobów Sieci liczne adresy stron, których otwieranie i przeglądanie może być tyle ciekawe, co i uciążliwe (pomijając inne miejsca, choćby katalog NUKAT podaje do obejrzenia ponad 280 opisów). Przeszukiwanie opisów w katalogu Biblioteki Narodowej prowadzi do wyboru kilku tytułów, zapowiadających wgląd do ich treści, tj. opatrzonych adnotacją „Zobacz: Reprodukcja cyfrowa w CBN Polona”. 
Sytuacja $2 b$.

Tabela 4. Sytuacja użytkownika poszukującego informacji i tekstów książek z zakresu przygotowywania dysertacji

\begin{tabular}{|l|l|l|}
\hline \multicolumn{2}{|c|}{ W środowisku Internetu } & W bibliotece (placówka) \\
\hline $\begin{array}{l}\text { WYNIKI: informacje handlowe o pu- } \\
\text { blikacjach (księgarska) (+ dodatkowe } \\
\text { charakterystyki) }\end{array}$ & & \\
WYNIKI: informacje o publikacjach & WYNIKI: & \\
uwzględnione w innych tekstach & kilka pozycji w re- & \\
(wzmianki, komentarze, recenzje, & produkcji Cyfrowej & \\
wyciągi i in.) & Biblioteki Narodowej & informacje: siw \\
WYNIKI: informacje - zestawy & (link z katalogu do & TREŚĆ: dostęp na miejscu, \\
tematyczne bibliograficzne przygoto- & POLONA), jednak & wypożyczenie \\
wane przez różne podmioty i różnych & brak dostępu do tych & \\
autorów & treści online, tylko & \\
WYNIKI: oferta publikowania pracy & lokalnie*) & \\
oraz inne oferty dla autorów doktoratów & & \\
WYNIKI: informacje zawarte w SIW & & \\
(biblioteczne, bibliograficzne) & & \\
\hline
\end{tabular}

*) dotyczy książek R. Kolman \& I. Szczepańska: Doktoraty i habilitacje: poradnik realizacji (2011), G. Gambarelli: Jak przygotować pracę dyplomowa lub doktorska (2001), J. Apanowicz: Metodologiczne uwarunkowania pracy naukowej: prace doktorskie, prace habilitacyjne (2005), T. Mendel: Metodyka pisania prac doktorskich (2010), K. Wójcik: Piszę akademicka pracę promocyjna: licencjacka, magisterską, doktorska (edycje 2005 i 2012), J. Pieter: Zarys metodologii pracy naukowej (1975).

Biorąc pod uwagę opisane powyżej starania użytkownika o dostęp do treści książek w przestrzeni cyfrowej, trudno nie zauważyć, że dostęp online do zawartości niektórych tytułów, za pośrednictwem technologii, należy po prostu kupić. Należy też powtórzyć, iż w wielu przypadkach (np. niedostępność w handlu, określone koszty) właściwym miejscem dostępu do treści jest biblioteka.

W Raporcie przytoczono również pogląd mówiący o tym, że popularne wyszukiwanie przez słowa kluczowe ma walor, m.in. odkrywania przez internautów materiałów pokrewnych i związanych z tematem lektur (kwerendy), co niejako nominuje sieć do roli nieocenionego i koniecznego przewodnika po świecie, dziedzictwie i nauce. Nie ma sensu powyższej opinii kwestionować. Środowisko informatyczne, wespół ze specjalistami innych dziedzin doskonali metody i narzędzia indeksowania i wyszukiwania informacji cyfrowej online. Stoję jednak na stanowisku, że wolny dostęp jako sposób udostępniania księgozbioru, znany z praktyki bibliotecznej, sprawdza się, a szczególnie wtedy, gdy po stronie użytkownika ma miejsce zainteresowanie, potrzeba poznania, motywacja zdobycia wiedzy.

Trzeba dodać, że podobnego zdania na temat udziału i ważności biblioteki w pracy indywidualnej jest Umberto Eco:

[...] jednym z nieporozumień, jakie dominują nad pojęciem biblioteki - pisał - jest pogląd, że idzie się tam po książkę, której tytuł się zna. [...] ale główną funkcją biblioteki [...] jest odkrywanie książek, których istnienia się nie podejrzewało, a które, jak się okazuje, są dla nas niezwykle ważne (Eco, 1990, 19-20).

Przypadki tu opisane nie wyczerpują rzecz jasna skali zróżnicowania sytuacji, jakie mogą być udziałem użytkownika poszukującego informacji o książkach (w szerokim rozumieniu 
tego słowa) oraz dostępu do właściwego tekstu. Nie starano się tu przedstawić wyczerpującego zbioru takich sytuacji. Powyższa egzemplifikacja wydaje się wystarczająca do zilustrowania poczynionych spostrzeżeń i dalszych nasuwających się wniosków w kontekście wymowy inspirującego moją wypowiedź Raportu.

\section{Wnioski}

Praktyka współczesnego uczestnictwa w kulturze odwołuje się do zasobów Internetu, w którym to środowisku istnieją łatwo dostępne informacje o różnym charakterze, dotyczące poszukiwanych książek lub ich autorów, wybierane automatycznie z zasobów Sieci.

Wyodrębniająca się grupa informacji o książkach składa się z informacji „z drugiej ręki”, obejmujących szereg form sygnalnych, komentatorskich, pochodnych czy związanych. Dodajmy, że badania korzystania z Internetu pokazują, że zdecydowana większość osób używa wyszukiwarki internetowej; w Polsce w 2012 r. wskaźnik ten wynosił 95.9\% (GUS, 2012, 133).

Wyraźnie zauważalne są też informacje o dostępności (lub jej braku) książki na rynku, które mogą ułatwić osobom jej zakup, a następnie stanowić źródło ważnych informacji dla obserwatorów rynku książki, dla badaczy aktywności ekonomicznej obywateli itp.

Doświadczenie współczesnego użytkownika zainteresowanego studiowaniem i zgłębianiem treści książek, charakteryzuje ograniczony (vide Tendencja 1.) dostęp do zawartości publikacji w Sieci, a którego uwarunkowania są rozpoznane. Podjęte przedsięwzięcia i środki zaangażowane w tworzenie bibliotek cyfrowych i repozytoriów przynoszą postęp. Jednocześnie - co trzeba powiedzieć wprost - korzystanie z dóbr cyfrowych stawia często użytkownika-czytelnika w sytuacji klienta.

Do tego dochodzi nieustanne zwiększanie ilości i mnożenie (multiplikacja) informacji cyfrowej, w tym przypadku o publikacjach, tj. ich anonsowanie, zdawkowe komentowanie, ogólnikowe opisy, zamieszczanie urywków, obrazków okładek i in., które może mieć wpływ na znajomość dzieł i lektur w społeczeństwie.

Przychodzi na myśl pogląd francuskiego literaturoznawcy Pierre'a Bayarda rozwinięty w publikacji o prowokacyjnym tytule Jak rozmawiać o ksiażkach, których się nie czytało (Bayard, 2008). Zauważa on słusznie, że między książką i czytelnikiem mogą zachodzić różne rodzaje relacji, a dokładne czytanie jest tylko jedną z nich. Istnieje też wiele sytuacji, miejsc stykania się z książkami, które zostawiają ślad w nas. Chodzi również o:

- książki przekartkowane (przejrzane),

- książki znane ze słyszenia,

- książki zapomniane (które stopniowo zacierają się w pamięci).

Już sam tytuł czy okładka przekształcają się w pierwszą opinię. Jak napisał przywołany autor, „[...] już w chwili, w której książka wkracza w pole naszej percepcji”, w pamięci zapisuje się ten zewnętrzny kontakt (Bayard, 2008, 21). Janusz Dunin w tekście O pożytkach z czytanych i nieczytanych książek (2005) zajął się specyfiką „czytelniczą” bibliofila i bibliotekarza, a także specjalisty w swoim zakresie, który na bieżąco dokładniej śledzi literaturę przedmiotu. Słuszne spostrzeżenia Dunin odniósł więc do szerszej grupy odbiorców:

Nie tylko badacze piśmiennictwa, bibliotekarze i bibliografowie, ale również zwykli czytelnicy znają zwykle więcej dzieł, niż udało się im w całości przeczytać (Dunin, 2005, 478). 
Pozostaje pytanie, którego Dunin nie stawia, co jednak zdaje się sugerować. Jest to pytanie o szczegółowość tego znawstwa, a także związane z tymże pytanie o sposób zapoznania się odbiorcy z dziełem. Zgadzam się z opinią cytowanego autora, że

odbiorca słowa drukowanego poznaje w czasie swego życia więcej pozycji z informacji pośrednich i pobieżnego oglądu, niż byłby w stanie przeczytać (Dunin, 2005, 478).

Obcowanie z książkami, podsuwa myśl Bayard, przybiera różne formy i jest czynnością intelektualną. Istotną rolę w nawiązaniu i pogłębianiu tej więzi odgrywa wykształcenie, wiedza i szerokie horyzonty. Francuski autor pisze o sobie następująco:

\footnotetext{
Nigdy na przykład nie <czytałem > Ulissesa [...] i najprawdopodobniej nigdy nie przeczytam. $<$ Zawartość> tej książki jest mi więc w znacznej mierze nieznana - z a wa r to ść , ale nie u s y t u o wan ie. Zresztą zawartość książki jest w dużej mierze usytuowaniem. Chodzi jednak o to, że bynajmniej nie czuję się niekompetentny, gdy przychodzi mi brać udział w rozmowie na temat Ulissesa [...]. Wiem, że schemat powieści opiera się na Odysei [...], że zastosowana w niej została technika strumienia świadomości, że akcja rozgrywa się w Dublinie w ciągu jednego dnia itd. Dlatego też, gdy prowadzę zajęcia, zdarza mi się przywoływać powieść Joyce’a bez mrugnięcia okiem (Bayard, 2008, 22).
}

Świat rozwiniętych technologii oferujących dostęp do mnóstwa informacji, niejako usposabia osoby do poruszania się w przestrzeni cyfrowej na poziomie informacji hasłowych i rozmaitych skrótów. Nie bez racji autorzy francuskojęzycznej wersji Raportu umieścili na stronie tytułowej tego dokumentu pytanie następujące: „na grzbiecie fali czy pod wodą?” (A la créte des vagues ou submerge par la marée?).

Moim zdaniem, wzrost pojawiających się w Sieci informacji dotyczących istniejących publikacji, kieruje w sposób szczególny spojrzenie na instytucję biblioteki i jej usługi. Użytkownik otrzymuje tam dostęp do dzieł, usług informacyjnych i specjalistycznej pomocy po spełnieniu - po stronie odbiorcy - określonych warunków, pośród których jednym z ważniejszych zdaje się być świadomość roli biblioteki i wiedza o jej nowoczesnym charakterze. Bardzo dużo zależy jednak od jakości nauczania na kolejnych poziomach rozwoju człowieka.

Pozostaje zauważyć, że najczęstszym miejscem korzystania z komputera jest dom (w 2012 r. wskaźnik wyniósł powyżej 61\%) i praca (w 2012 r. wskaźnik wyniósł 19\%), a nie np. szkoła/uczelnia, czy tzw. inne miejsca, tj. miejsca publiczne, jak biblioteki, kawiarenki internetowe (wskaźniki odpowiednio: 8 i 3\%). Jak czytamy w raporcie:

W krajach europejskich udział osób korzystających z komputera w domu jest również najwyższy w porównaniu z innymi miejscami. Poza odsetkiem osób używających komputer w szkole lub na uczelni, korzystanie z tego urządzenia w innych miejscach jest w Polsce mniej popularne niż w skali całej Unii Europejskiej (GUS, 2012, 97-98).

Jest przy tym faktem, o czym była mowa, że wytwory pracy biblioteki w postaci systemów informacyjno-wyszukiwawczych o posiadanych zasobach, stały się dobrem włączonym do ogólnodostępnej cyfrowej przestrzeni informacyjnej i są ważne dla jej użytkowników.

Biblioteki weszły kilkadziesiąt lat temu na drogę stosowania i użytkowania nowoczesnych technologii. Odzwierciedleniem postawy środowiska świadomego atutów swojej profesji oraz jakości przekształcanych warsztatów pracy, są wypowiedzi piśmiennicze, w których ich autorzy wysoko oceniają uzyskany i proponowany potencjał. W tej części zasoby Internetu opisane są cechami takimi jak: aktualność, całodobowa dostępność, poprawność, 
rzetelność, spójność danych, wiarygodność (Antczak-Sabala et al., 2009; Wrocławska, Jerzyk-Wojtecka, 2006).

Współczesne biblioteki funkcjonują w otoczeniu nauki, inne są elementem polityki kulturalnej. Ujęcie przyszłościowe obecne w Raporcie, wskazujące m.in. na rozkwit „nowych modeli biznesowych", obejmujących dochodowy rynek pośredników i dostawców informacji oraz sektor e-nauczania, uzasadnia istotne pytanie. Obok pytania ekspertów IFLA o to, jak biblioteka zareaguje na przewidywane zmiany („,comment [...] bibliothèque réagira-t-elle aux scénarios suivants?”), ciśnie się kolejne pytanie o to, jak na te zmiany mogą zareagować użytkownicy, potencjalne środowisko osób zdobywający i zgłębiający wiedzę?

\section{Bibliografia}

Antczak-Sabała, B.; Kowalska, M.; Tkaczyk L. red. (2009). Przestrzeń informacyjna biblioteki akademickiej - tradycja i nowoczesność. Toruń: Wyższa Szkoła Bankowa.

Bayard, P. (2008). Jak rozmawiać o ksiażkach, których się nie czytało. Warszawa: PIW.

Diagnoza społeczna 2011. Warunki i jakość życia Polaków [online]. Contemporary Economics. Quarterly of University of Finance and Management in Warsaw, 5, [2.02.2014], http://ce.vizja.pl/en/ issues/volume/5/issue/3\#art220

Diagnoza społeczna 2013. Warunki i jakość życia Polaków [online]. Contemporary Economics. Quarterly of University of Finance and Management in Warsaw, 7, [27.02.2014], http://ce.vizja.pl/ en/issues/volume/7/issue/3.1

Dunin, J. (2005). O pożytkach z czytanych i nieczytanych książek. Roczniki Biblioteczne XLIX, 477-486.

Eco, U. (1990). O bibliotece. Wrocław: „Ossolineum”.

GUS (2012). Społeczeństwo informacyjne w Polsce. Wyniki badań statystycznych $z$ lat 2008-2012 [online]. Główny Urząd Statystyczny [5.01.2014], http://stat.gov.pl/cps/rde/xbcr/gus/nts_spolecz_inform_w_polsce_2008-2012.pdf

IFLA (2013). À la crête des vagues, ou submergé par la marée. Naviguer dans un environnement de l'information en mutation. Aperçu du Rapport sur les tendances [online]. IFLA - The International Federation of Library Associations and Institutions [6.03.2014], http://trends.ifla.org/insights-document ISP (2014a). Publikacje. Elektroniczne książki [online]. Instytut Spraw Publicznych [12.05.2014], http://isp.org.pl/site.php?id=213

ISP (2014b). Szczegóty publikacji. „Kobiety, wybory, polityka” [online]. Instytut Spraw Publicznych [12.05.2014], http://isp.org.pl/ksiegarnia,publikacja,61,568.html

MAC (2010). E-administracja w oczach internautów [online]. Ministerstwo Administracji i Cyfryzacji [12.02.2014], http://szs.mac.gov.pl/SZS/aktualnosci/8684,E-administracja-w-oczach-internautow.html

MAC (2012a). E-administracja w oczach internautów [online]. Ministerstwo Administracji i Cyfryzacji [12.02.2014], https://mac.gov.pl/files/wp-content/uploads/2011/12/e-administracja-w-oczach-internautów-2012.pdf

MAC (2012b). Społeczeństwo informacyjne w liczbach [online]. Ministerstwo Administracji i Cyfryzacji, [13.05.2014], http://maic-info.minus.com/

MAC (2013). Społeczeństwo informacyjne w liczbach 2013 [online]. Ministerstwo Administracji i Cyfryzacji [11.02.2014], http://www.cyfrowyurzad.pl/aktualnosci/raport-spoleczenstwoinformacyjne-w-liczbach-2013-jest-juz-dostep,art647.html

Pikulska, I. (2009). Dwudziestowieczne biografie literackie Fryderyka Chopina (Juliusz Kaden-Bandrowski - Adolf Nowaczyński - Kazimierz Wierzyński - Jarosław Iwaszkiewicz). Katowice: Uniwersytet Śląski, Wydział Filologiczny [4.03.2014], http://www.europeana.eu/portal/record/09404/ id_oai_www_sbc_org_pl_12716.html

Wrocławska, M.; Jerzyk-Wojtecka, J. red. (2006). Stare i nowe w bibliotece. Łódź: Wydaw. UŁ. 


\title{
Trends in the Development of Information and the Information Situation of Book Users
}

\begin{abstract}
Purpose/thesis: The purpose of the paper is to review IFLA document entitled Rapport sur les tendances and use it as a background for the analysis of the situation of book users.

Approach/methods: The following methods were used: the review of IFLA document, the analysis of selected literaturę, the interpretation of source data, the description and evaluation of several cases illustrating the situation of book users.

Results and conclusions: The prediction covers: 1) information availability, 2) e-learning, 3) security and protection of private life, 4) citizen involvement, 5) information management, and emphasizes the development of business models in providing access to information. Online information on publications may refer book users to the library collections, often makes them customers of given companies, helps them to purchase the documents and provides market observers with specified information. The digital world, offering access to information on books, may predispose its users to navigate it with headings and shortcuts. The current question is how the book users will respond to this situation.

Originality/value: The author summarizes the content of IFLA document and states her opinion on the predictions included there. The topic discussed in this paper so far has not been raised in the literature of the field.
\end{abstract}

\section{Keywords}

Access to information. Digital age. Information. Internet. Reading. Information Society. Information user.

Dr hab., prof. UŁ STANISEAWA KUREK-KOKOCIŃSKA jest pracownikiem naukowym Katedry Bibliotekoznawstwa i Informacji Naukowej Wydziału Filologicznego Uniwersytetu Łódzkiego. Zajmuje się problematyką: kultury książi i informacji w społeczeństwie wiedzy. Ostatnie publikacje to m.in.: Rozwój bibliografii chopinowskiej w Polsce. Zagadnienia Informacji Naukowej 2013 (1); Być bibliotekarzem i pracować w bibliotece. Przeglad wyników badań. Zagadnienia Informacji Naukowej 2012 (2); Z upodobania do czytania: kultura książi wieku dziecięcego w świetle wypowiedzi wspomnieniowych. W: Książka i prasa w kulturze. Red. K. Domańska, B. Iwańska-Cieślik. Bydgoszcz: Wydaw. Uniw. Kazimierza Wielkiego, 2013, 342-353.

Kontakt zautorem: kokos@uni.lodz.pl

Katedra Bibliotekoznawstwa i Informacji Naukowej

Wydziat Filologiczny

Uniwersytet Łódzki

ul. Matejki $34 a$

91-463 Łódź 